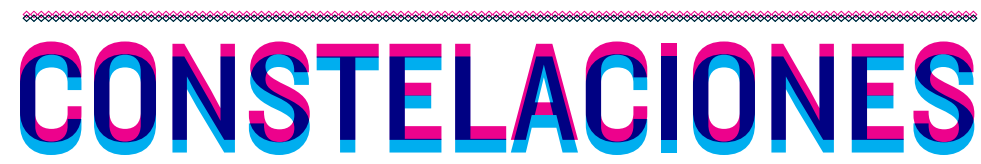

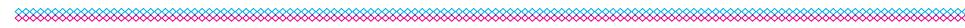


CONSTELACIONES n¹, mayo 2013

Revista de Arquitectura de la Universidad CEU San Pablo

Architecture magazine of CEU San Pablo University

Periodicidad anual

Annual periodicity

COMITÉ DE REDACCIÓN EDITORIAL COMMITTEE

Director Director

Juan García Millán

Director de Arte Art Director

Juan Roldán Martín

Jefa de Redacción Editor in Chief

Covadonga Lorenzo Cueva

Secretario de Redacción Editorial Clerk

Rodrigo Núñez Carrasco

Ayudante de Redacción Assistant

María Fernández Hernández

Vocales Board Members

Javier Domínguez. Escuela Superior de Enseñanzas Técnicas, Universidad CEU Cardenal Herrera, Valencia

Teresa Franchini. Escuela Politécnica Superior, Universidad CEU San Pablo, Madrid

Alejandro Gómez. Escuela Politécnica Superior, Universidad CEU San Pablo, Madrid

Aurora Herrera. Escuela Politécnica Superior, Universidad CEU San Pablo, Madrid

Mariano Molina. Escuela Politécnica Superior, Universidad CEU San Pablo, Madrid

Alberto Sanjurjo Álvarez. Escuela Politécnica Superior, Universidad CEU San Pablo, Madrid

CONSEJO EDITORIAL EDITORIAL BOARD

Beatriz Colomina. School of Architecture, Princeton University, New Jersey

Carmen Díez Medina. Escuela de Ingeniería y Arquitectura, Universidad de Zaragoza

María Antonia Frías Sargadoy. Escuela Técnica Superior de Arquitectura, Universidad de Navarra

Ángel González García. Facultad de Geografía e Historia, Universidad Complutense de Madrid

Juan Miguel Hernández Léon. Escuela Técnica Superior de Arquitectura, Universidad Politécnica de Madric

Juan José Lahuerta. Escuela Técnica Superior de Arquitectura, Universidad Politécnica de Cataluña, Barcelona

Eduardo Leira. Ex director del Plan General de Ordenación Urbana, Madrid

Joaquín Medina Wamburg. Facultad de Aquitectura Diseño y Urbanismo, Universidad de Buenos Aires

Zaida Muxí. Escuela Técnica Superior de Arquitectura, Universidad Politécnica de Cataluña, Barcelona

José Joaquín Parra Bañón. Escuela Técnica Superior de Arquitectura, Universidad de Sevilla

Víctor Pérez Escolano. Escuela Técnica Superior de Arquitectura, Universidad de Sevilla

Fernando Pérez Oyarzún. Escuela de Arquitectura y Diseño, Pontificia Universidad Católica, Santiago de Chile Judith Sheine. School of Architecture and Allied Arts, University of Oregon, Portland

Andrés Walliser. Global Design, New York University, Nueva York
Queremos expresar nuestro agradecimiento a Luis Fernández-Galiano, Rafael Moneo y Juan Navarro Baldeweg por sus sabias y desinteresadas sugerencias. We would like to express our sincere gratitude to Luis FernándezGaliano, Rafael Moneo and Juan Navarro Baldeweg for their wise and selfless suggestions.

ISSN 2340-177X

Depósito legal M-13872-2013

(c) de los textos, sus autores

(c) de las imágenes autorizadas

(c) Revista Constelaciones

C Escuela Politécnica Superior, Universidad CEU San Pablo

Universidad CEU San Pablo

Escuela Politécnica Superior

Urbanización Montepríncipe, s/n

Boadilla del Monte, 28668. Madrid (España)

constelaciones@eps.ceu.es

www.uspceu.es

Edición Edition

Fundación Universitaria San Pablo CEU

Madrid, España

Impresión Printing

VA Impresores

Impreso en España Printed in Spain

Distribución Distribution

CEU Ediciones

Los textos que componen Constelaciones se obtienen mediante convocatoria pública. Para que los trabajos recibidos entren en el proceso de selección de los artículos a publicar deben ser trabajos originales no publicados anteriormene, con una extensión recomendada de 3.000 palabras, título, resumen (un máximo de 150 palabras) y palabras clave (un mínimo de cuatro palabras), en español y en inglés. Tras haber cumplido estos requisitos (y los correspondientes incluidos en las normas editoriales de la revista, disponibles para consulta en formato digital desde el comienzo de la convocatoria), tiene lugar un proceso de revisión y evaluación de los artículos previa aceptación de los mismos para su publicación. Para acometer dicho proceso, y con el fin de asegurar la calidad de los contenidos, la Revista Constelaciones recurre a evaluadores externos a la institución editora y anónimos (cada artículo es evaluado por dos de ellos) encargados de someter a crítica los mismos. Todos los artículos de investigación publicados en esta revista han pasado por dicho proceso. La recepción de artículos se extendió hasta el 30 de Septiembre de 2012. Texts included in Constelaciones are obtained by public announcement. Only original papers that have not been previously published will be included in the process of selection of articles. They should not exceed 3.000 words and should include a title, an abstract (no more than 150 words) and keywords (a minimum of four words), in Spanish and English. After having fulfilled these requirements (and those included in magazine editorial standards, available for consultation from the beginning of the Call for Papers), occurs a process of review and evaluation of articles upon acceptance of them for publication. To undertake this process, and in order to ensure the quality of the contents, Constelaciones turns to external and anonymous evaluators to the institution (each article is evaluated by two of them) responsible for the critic. All the articles published in this journal have undergone this process. The deadline for reception was extended until September 30, 2012.

Todos los derechos reservados. Esta publicación no puede ser reproducida, ni en todo ni en parte, ni registrada, ni transmitida, ni almacenada en ningúna forma ni por ningún medio, sin la autorización previa y por escrito del equipo editorial. En este número se han utilizado algunas imágenes de las que no se ha podido identificar al propietario de los derechos. En estos casos hemos entendido que las imágenes son de libre uso. En caso de identificar alguna de estas imágenes como propia, por favor, póngase en contacto con la redacción de Constelaciones. Los criterios expuestos en los diversos artículos de la revista, son responsabilidad exclusiva de sus autores, y no reflejan necesariamente los que pueda tener el equipo editoral. El equipo editorial de la revista no se responsabiliza de devolver la información enviada a la redacción a no ser que se le solicite expresamente. All rights reserved. This publication cannot be reproduced, in whole or in part, nor registered, transmitted or stored in any form or by any means, without the written permission of the Editorial team. In this issue some images were used without knowing the ow ima with the Edito this journal. The publisher don't take responsibility for returning submitted material which is not expressly requested. 


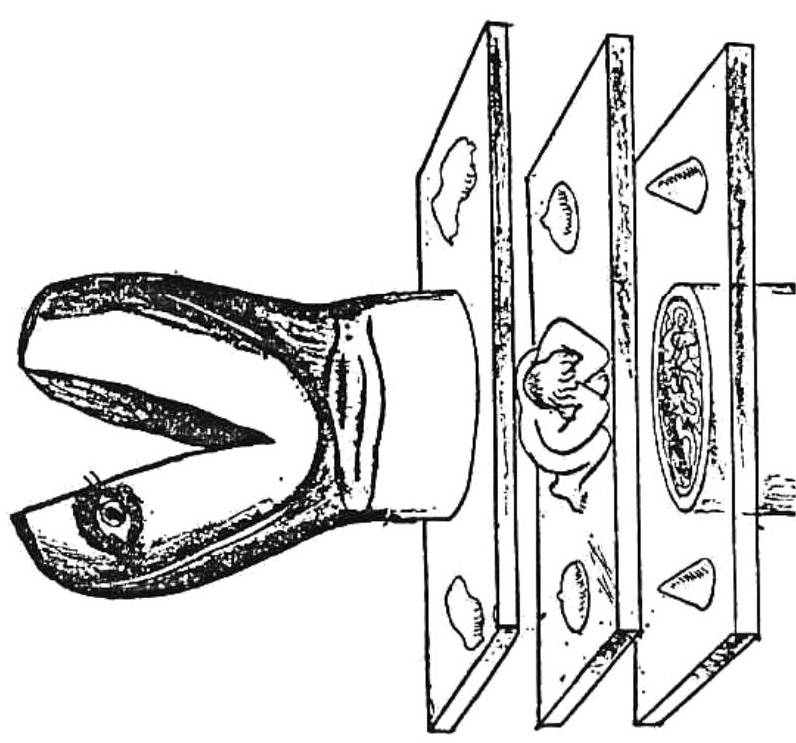




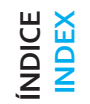

$\therefore N$

ร

ス

$\infty$

음

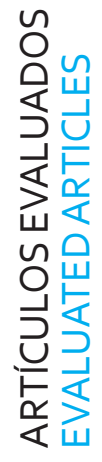

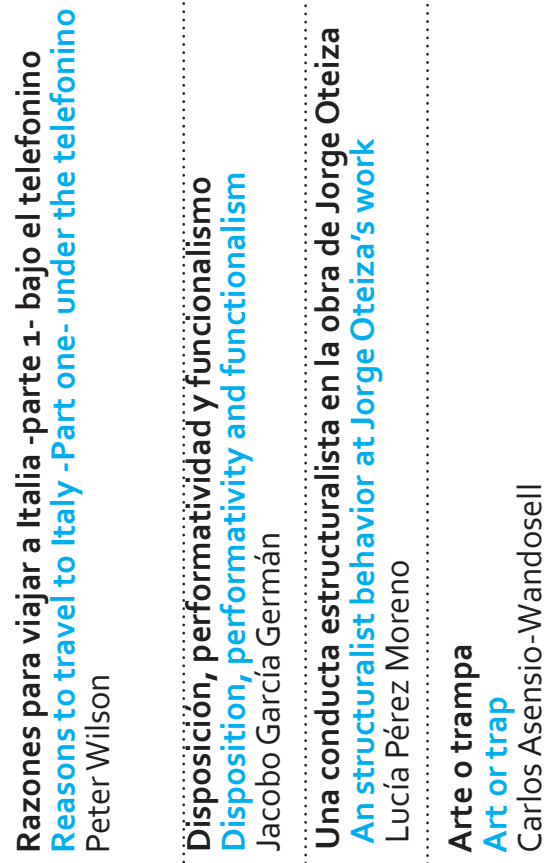

음

ํㅡㄹ 질

즈 릴

눙

送

흉

क을

t

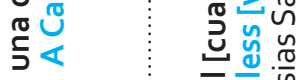

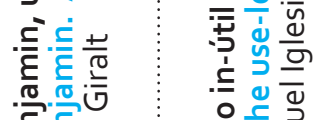

एँ

으동

ตั

可安

$3 \frac{\pi}{3} \frac{\pi}{3}$

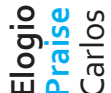

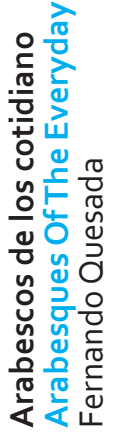

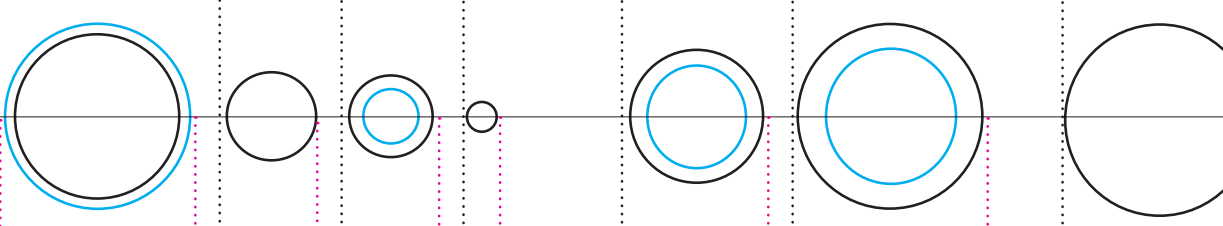

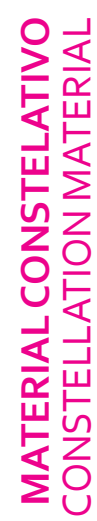

岂岕
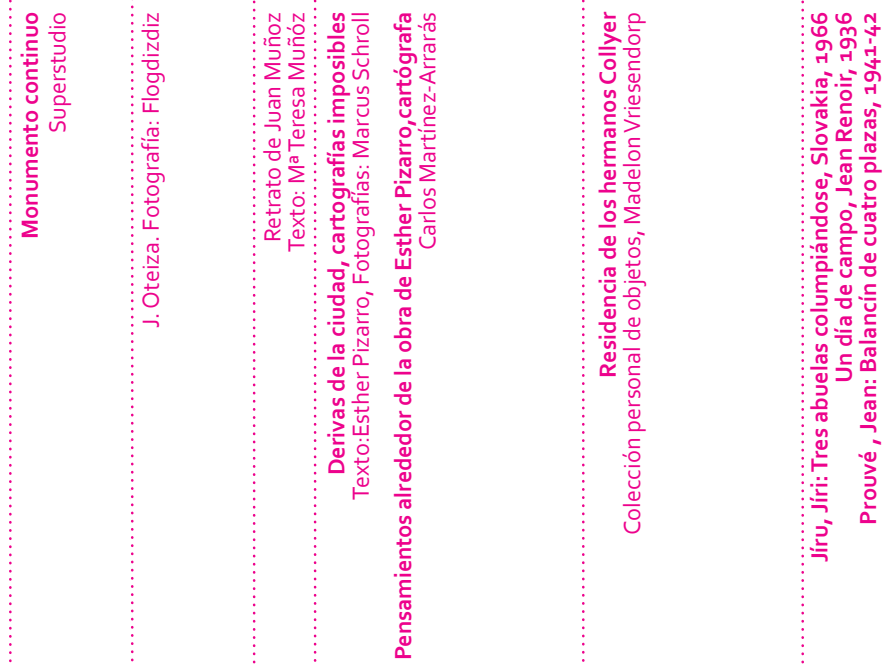

ले g

$\infty$

으 

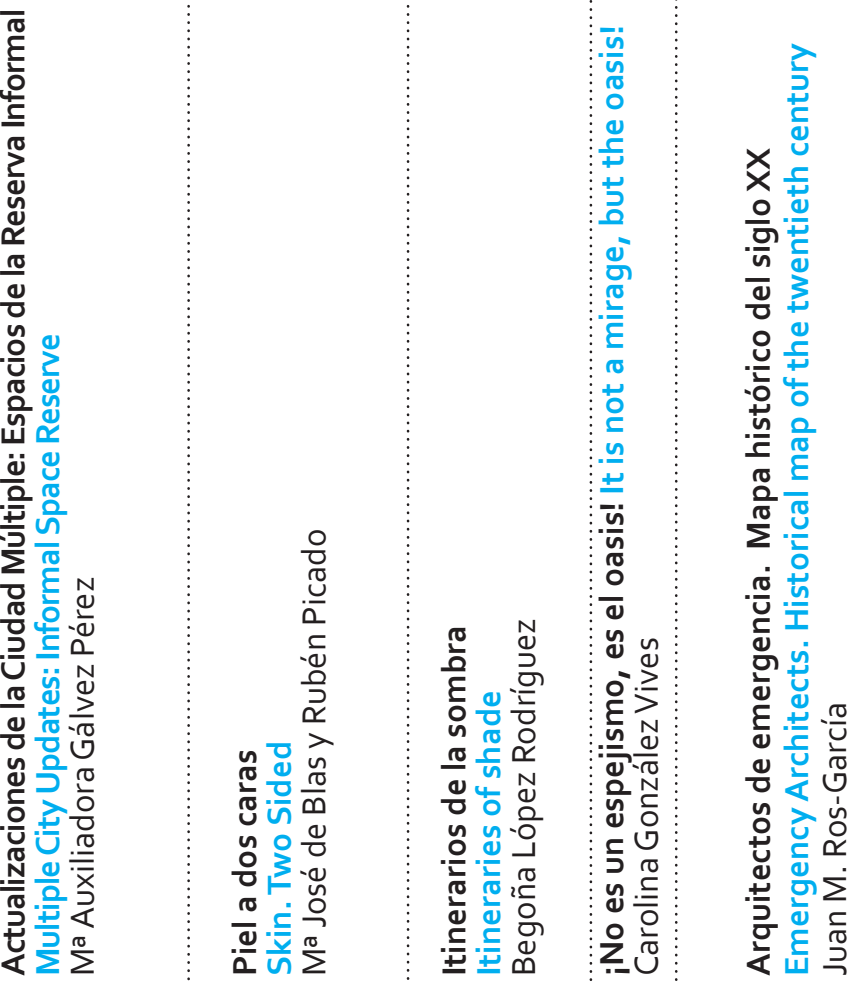

옳

ㄷํㄹ 든

ปี่

ชับ응

준 뜬

ปับำ

운 은 은

要范

은 눈 Nㅜㄴ

뜨드

둥

产 施

은

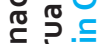

ㄴํㄴ

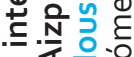

눙ㅁㅇ

즌 원응

던 늠

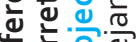

幽交 인

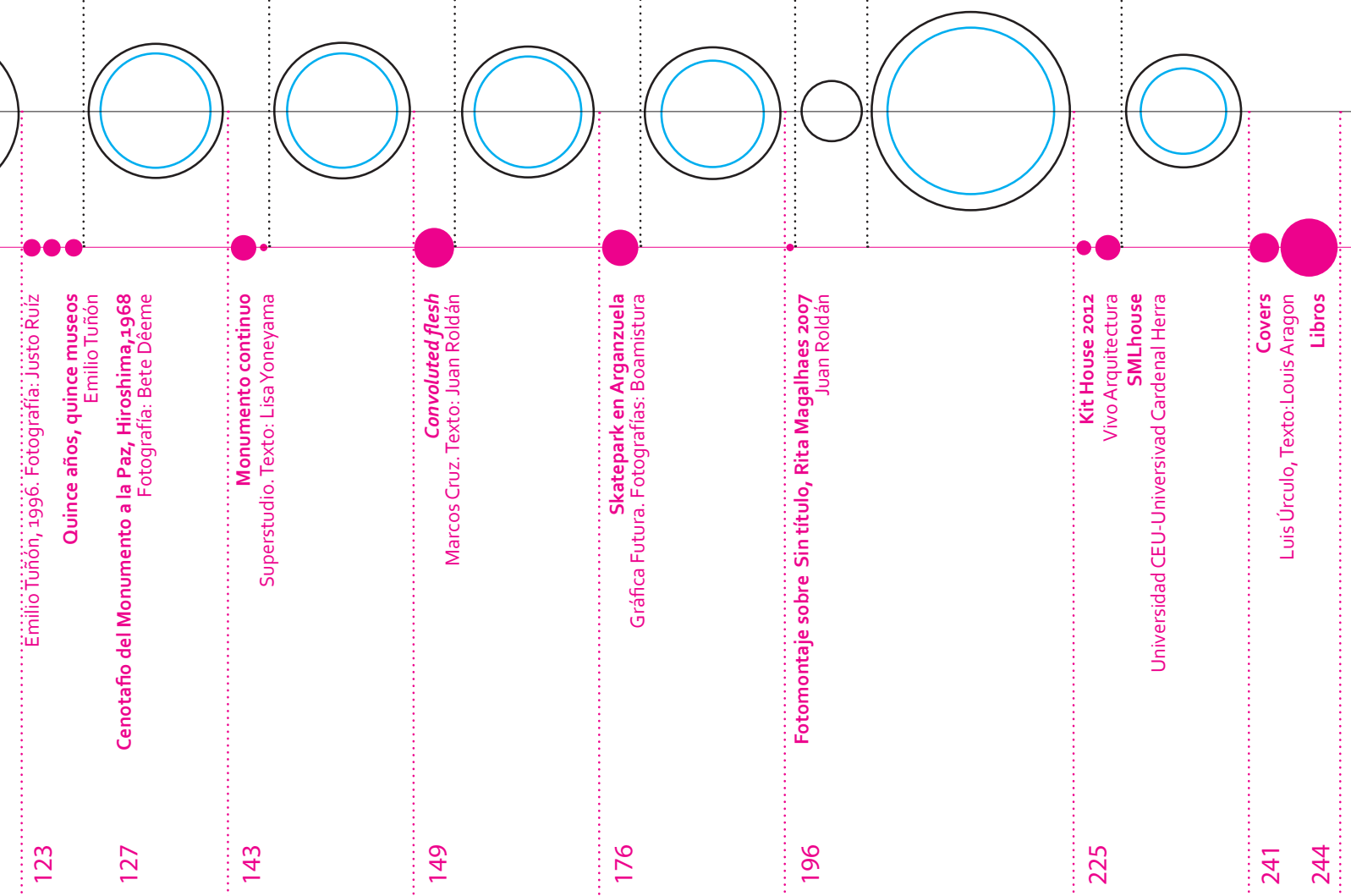




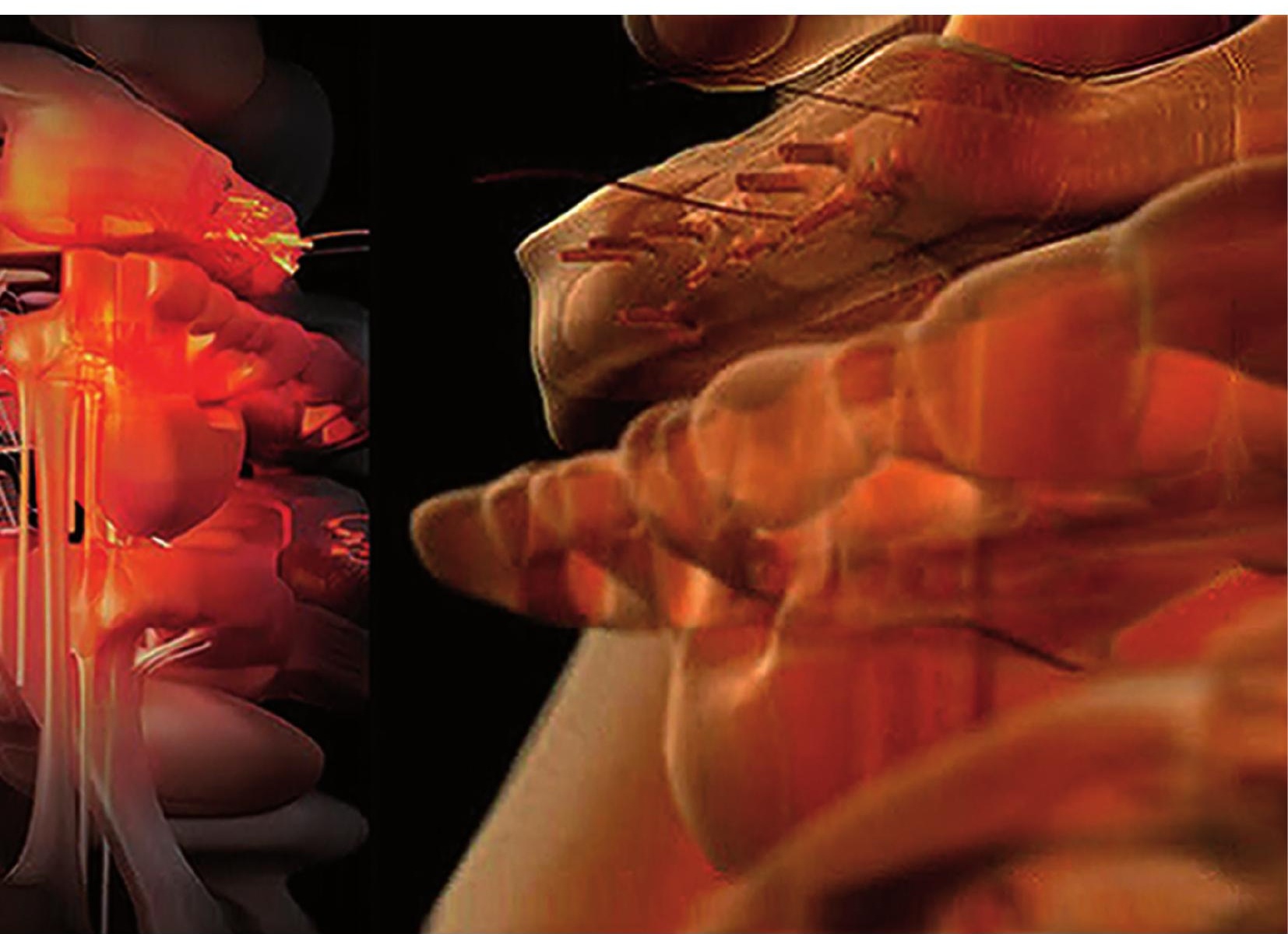




\title{
Piel: a dos caras
}

\section{Skin: Double Sided}

\author{
María José de Blas y Rubén Picado \\ Escuela Politécnica Superior, Universidad CEU San Pablo, Madrid
}

Traducción Translation Ana Alonso Albarracín

\section{Palabras clave Keywords}

piel, cara, capa, Utzon, envolvente skin, face, layer, Utzon, enveloping

\section{Resumen}

Denominar 'piel' a una membrana con cualidades casi bidimensionales ha sido la metáfora más generalizada de la arquitectura desde el siglo XX. En los años cincuenta se concentra un giro de guión en el planteamiento ético constructivo. Utzon abrirá un camino sorprendente.

Se analizan obras de Saarinen, Le Corbusier y Fisac que juegan con la piel. Fuller, 0tto y Archigram recogen el testigo epitelial desde la ligereza y lo nómada. Venturi, precursor del Posmodernismo es complaciente con la ética constructiva, justificando que la piel expresiva de la arquitectura trabaje de forma independiente y autónoma al orden interno, iprecisamente el cuarto punto de Le Corbusier! Las Vegas es el ejemplo vivo de ello. En todos estos puntos de vista hay una preocupación común, vemos cómo la piel, sea o no estructural, cáscara o membrana, monomatérica o multicapa es el problema más vulnerable que manipula el arquitecto, por albergar la inevitable imagen de lo construido, el límite de las cosas.

\section{Abstract}

Naming 'skin' a membrane with almost bi-dimensional qualities has been the most generalized architectural metaphor since the XXth century. A shift in the script of the approach to constructive ethics takes place in the 50's. Utzon will uncover a surprising path.

Works by Saarinen, Le Corbusier and Fisac, which play with skin, are analysed. Fuller, 0tto and Archigram receive the epithelial baton through the light and nomadic. Venturi, forerunner of Posmodernism, is indulgent with constructive ethics, justifying that the expressive skin of architecture works independently and autonomously from its internal order, precisely Corbusier's 4th point! Las Vegas is the living example of this. In all these points of view, there is a common concern: we observe how the skin, be it structural or not, shell or membrane, of a single component or multilayered, is the most vulnerable aspect manipulated by the architect, for it hosts, the inevitable image of what is built, the limit of things. 
Denominar 'piel' a una membrana con cualidades casi bidimensionales ha sido la metáfora más generalizada que ha transmitido la arquitectura desde el principio del siglo $\mathrm{xx}$, un término procedente del ámbito biológico. La piel es un tejido vivo de sujeción flexible, cuya estructura interna trabaja íntegramente a tracción; con un simple corte se abre. Es el órgano más grande de nuestro cuerpo, lo protege y sirve de comunicador. Su condición envolvente y tensa oculta su complejidad. Como algo casi homotético construimos nuestra casa con otra piel artificial. El intersticio entre nuestra piel y la materia es el espacio arquitectónico. Las pieles definitivamente son las que reflejan el límite perceptivo.

En nuestro cuerpo, la piel protege y realiza ciertas funciones de regulación que permite adaptarnos a distintos entornos, prepara y reacciona con nuestro organismo frente a situaciones de esfuerzo físico o emoción. Nos relaciona con el mundo a través de lo táctil, como apunta Juhani Pallasmaa en Los ojos de la Piel. La piel arquitectónica contiene el límite que establece las regulaciones con el entorno que nos rodea. Mayor será la especialización y complejidad cuanto más hostil sea el medio del que protegerse. Tiene la capacidad de generar ambigüedad.

Por tanto, el límite de un edificio es una piel con características propias y diversas variables que han evolucionado sustancialmente en el tiempo por cuestión de adaptación, selección del tipo, tecnología y estilo. Materializa el rostro de la arquitectura y, al igual que nuestro propio cuerpo, muestra de qué estamos hechos, cómo somos, en qué medio habitamos o qué edad tenemos, evidencia y explica con qué tecnología se ha pensado y define cómo se responde al lugar en que se inserta.

La piel de la arquitectura ha evolucionado de lo monomatérico y masivo, mas primitivo, hacia la sintaxis de capas ligeras y transparentes. Va perdiendo su condición estructural de cáscara rígida, (Fig. 1) hacia tejidos complejos (Fig. 2) que pueden incluso conducir libremente las cargas superficialmente con materiales casi sin peso. ¿La tendencia evolutiva tendrá su fin en la definitiva disolución física de los límites? Quizá, eso ocurra en acciones

Naming 'skin', a term from the biological sphere, a membrane with almost bidimensional qualities has been the most generalized metaphor transmitted by Architecture since the beginning of the 20th century. The skin is a live tissue of flexible support, with an internal structure that works exclusively in tension; it opens up with a simple cut. It is the largest organ of our body, protecting it and serving as communicator. Its enveloping, tensed condition conceals its complexity. Almost as in homothetic transformation, we build our homes with artificial skins. The interstice between our skin and the constructed one is the architectural space. Skins are definitely what determine the perceptive limit.

The body's skin protects it, and carries out certain functions of regulation that enable us to adapt to different environments. It prepares and reacts together with the organism to situations of physical effort or emotion. It relates us with the outer world through what is tactile, as Juhani Pallasmaa points out in The Eyes of the Skin. The architectural skin contains the limit that establishes regulations with the surrounding environment: the greater the hostility of the medium, the greater the skin's complexity and specialization.

It has the capacity of generating ambiguity. The limit of a building is therefore a skin with its own characteristics and diverse variables which have evolved 


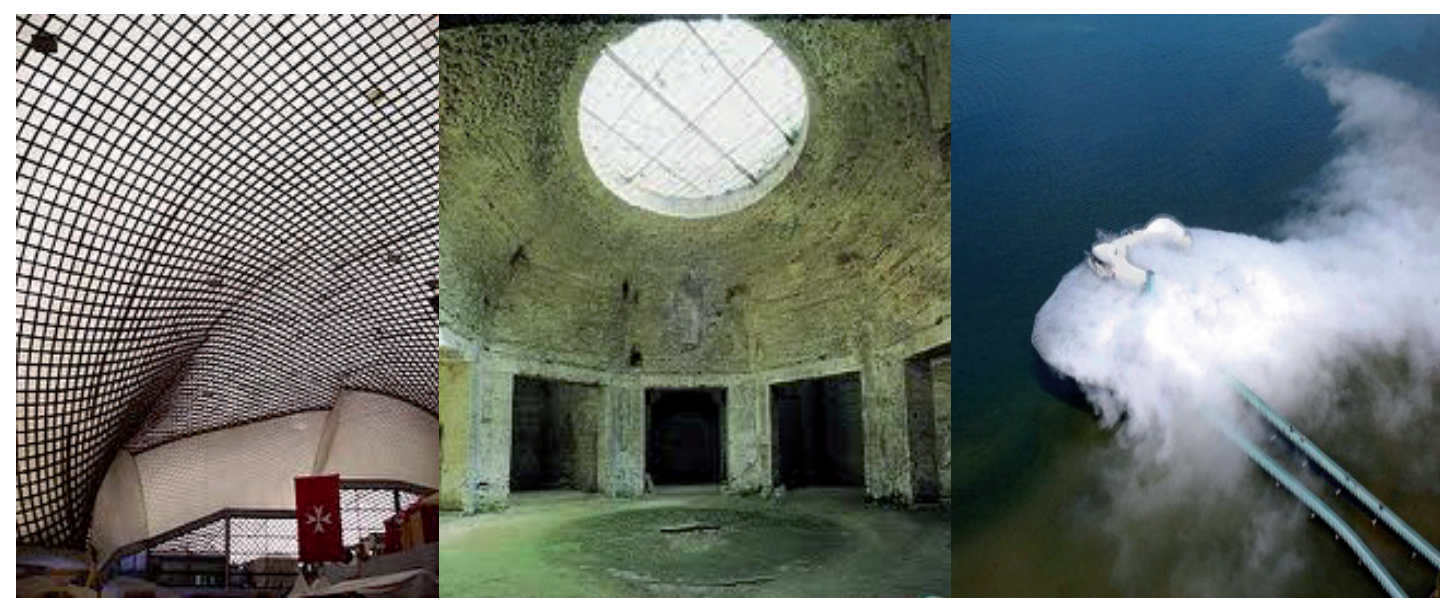

artísticas, (Fig. 3) aunque no parece que deban diluirse tan fácilmente cuando lo que está en juego es habitar.

El muro masivo se traza en el territorio y en su materialización, se personaliza a través de sus dos caras; podríamos decir con dos pieles vistas sin espesor, exterior e interior, separadas originalmente por solo materia. El espesor del muro es variable e irrelevante.

Lo que más se precisaba, sobre todo en la arquitectura primitiva, eran las relaciones arquitectónicas del espacio que encierra la superficie de la cara interior del muro. Ese espacio se controlaba con sencillos trazados reguladores geométricos, con el fin de encontrar armonías visuales y numéricas hasta llegar a los cánones de belleza o líneas a seguir, centradas en la emoción de la forma. Desde Vitrubio hasta Camilo Site, quedaron dibujadas instrucciones en multitud de tratados, con relaciones proporcionales que definían verdades académicas.

La piel exterior es la fachada que nunca se ha descrito en estos libros como resultado de un contexto urbano, sino como el resultado de una serie de relaciones ensimismadas en las proporciones de unidades que se repiten,

substantially in time, for reasons of adaptation, type selection, technology and style. It materializes the face of Architecture and, as our own body does, it shows what we are made of, how we are, in what medium we live or what our age is. It evidences and explains with what technology it has been thought of and defines a response to the site where it is inserted.

The skin of Architecture has evolved from the more primitive and massive, towards syntaxes of light and transparent layers. It loses its structural condition of rigid shell, (Fig. 1) becoming complex tissues (Fig. 2) that can even conduct loads superficially through almost weightless materials. Will the evolutionary tendency end with the physical dissolution of the limits? Such thing may occur in artistic interventions, (Fig. 3) but it does not seem that dilution should happen so easily when inhabiting is what is at stake. The massive wall is traced on the territory, and with its materialization it is impersonated by its two sides, may we say two exposed skins with no thickness, interior and exterior originally separated only by matter. The thickness of the wall is variable and irrelevant.

The architectural relationships of the space enclosed by the wall's interior surface are what was most required, especially in primitive architecture. Such space was controlled through simple geometrical, regulating tracings, with the intention

Fig. 1. Otto, Frei: Multihalle, Manheim, 1975.

Fig. 2. Domus Aurea, Roma, 84 a.C.

Fig. 3. Diller \& Scofidio, Blur Building, Lausana, 2002. 
basadas en antiguos conocimientos antropométricos. La fachada es la consecuencia más vulnerable del hecho constructivo, lejos del control geométrico interior y que, en pocas ocasiones, resuelve el espacio urbano con la misma entereza o rotundidad que vemos en los interiores. Seguramente, el que la piel exterior pertenezca al ámbito público, provoca que todo acabe contagiado de otros criterios más cercanos a la representatividad política que a la belleza y la armonía, términos en desuso, que hoy día con cierto eufemismo denominamos pertinencia o sostenibilidad.

Este desequilibrio o doble expresividad entre el exterior y el interior, es evidente incluso en el Panteón. (Fig. 4) Afortunadamente, la historia ha respetado su esencia interior, desnudándole sólo de sus pieles ostentosas, dejándonos momificado a través de sus muros lo más valioso, la luz que da vida a ese espacio. Sin embargo, seis metros detrás de ese muro cilíndrico de veinticinco metros de alto, vemos como su cara exterior no responde, hoy en día, al contexto urbano de forma tan emocionante, no ha aguantado el paso del tiempo como lo ha hecho su cara interior.

Por tanto, es interesante pararse a pensar que las construcciones más primitivas encierran el concepto más abstracto: un muro, con dos caras y tres capas (dos son pieles sin espesor y con textura, que envuelven otra interior material e invisible). Veremos lo que ocurre cuando esa concepción inmediata de la materia, se empieza a distorsionar para evolucionar hacia la búsqueda de otras sensaciones espaciales.

El maestro Brunelleschi da un paso importante a través de la técnica constructiva precisamente en este ámbito que pretendemos analizar. Diseña en el año 1420 la cúpula del Duomo (Fig. 5) de Florencia, en la cual prima la presencia urbana. Es justo el interés contrario al Panteón, aquí es el aspecto de la piel exterior el prioritario. Por tanto su viabilidad pasa por pensar en cómo aligerarla, no es posible cincelar la materia de forma monolítica de forma primitiva. Lo hace a través de dos hojas, donde cada una de ellas da respuesta al espacio que le corresponde, la interior al crucero del templo y la exterior a la presencia en la cuidad.

of finding visual and numeric harmonies that reached the canons of beauty; or through lines to follow, centered on the emotion of form. From Vitruvius to Camilo Site, instructions were left drawn on a multitude of treaties, with proportional relationships defining academic truths.

The exterior skin is the façade, which has never been described in the mentioned books as the result of an urban context, but rather as the result of a series of relationships absorbed with repeated proportions of units, based on old anthropometric knowledge. The façade is the most vulnerable consequence of the constructive fact, far from the geometrical control of the interior and which in few occasions resolves urban space with the same integrity or clarity as we see it does in interior spaces. Surely the skin's belonging to the public realm is the cause for everything else to be contaminated by other criteria, closer to political representation than to beauty and harmony -outdated terms which we nowadays name, with a certain euphemism, pertinence or sustainability.

This lack of equilibrium or double expressivity between exterior and interior is evident even in the Pantheon (Fig. 4). Fortunately, history has respected its interior essence, stripping it only of the ostentatious skins, leaving what was most valuable mummified between its walls: the light that brings life to that space.

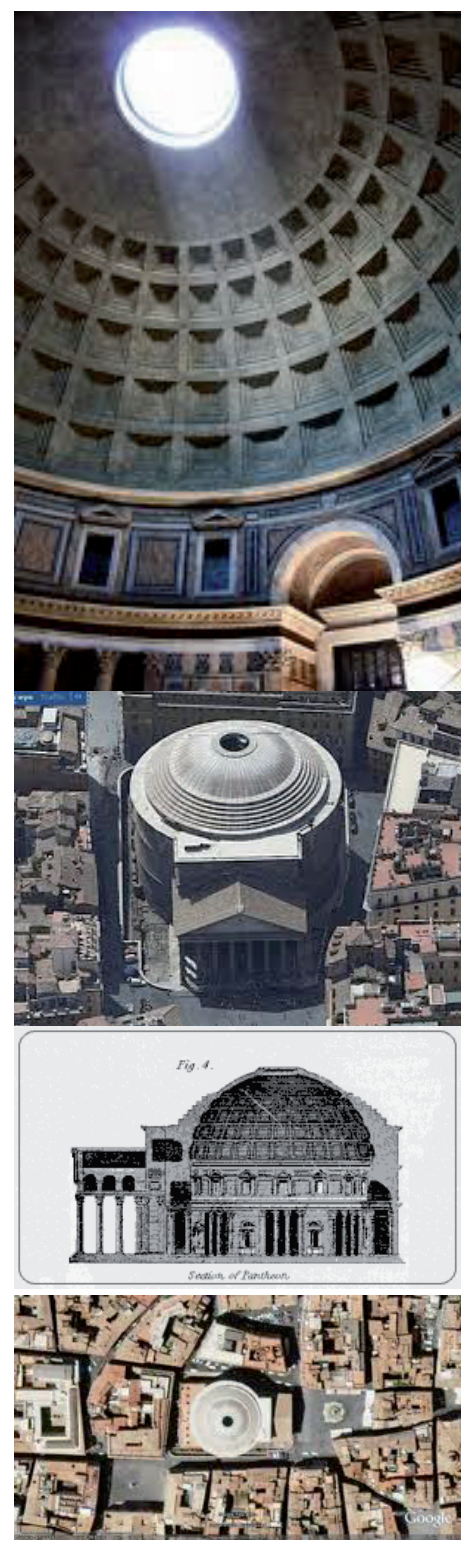

Fig. 4. Panteón, $125 \mathrm{dC}$. 

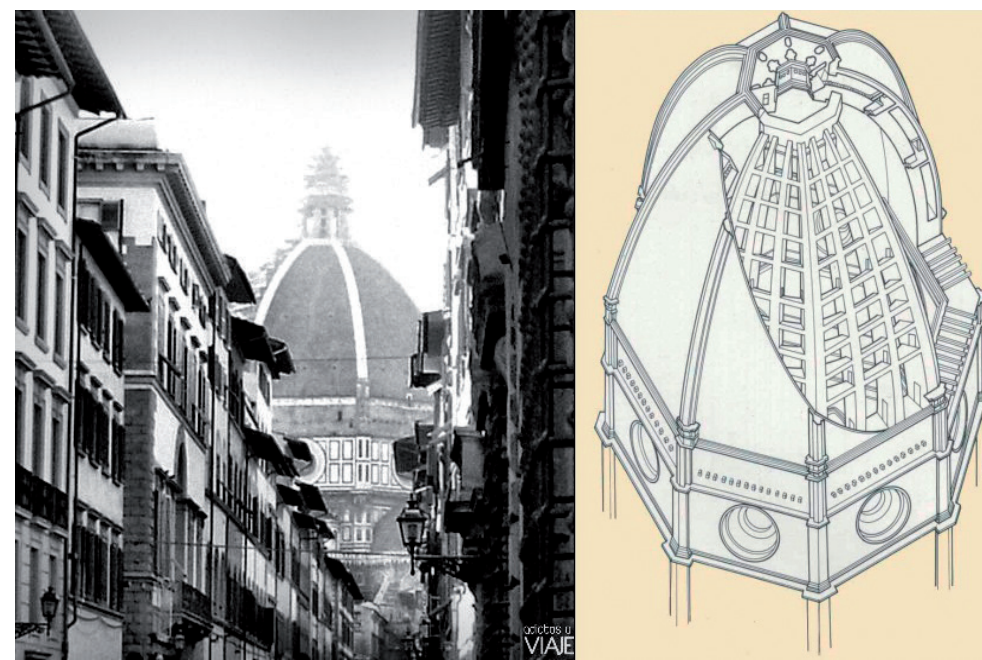

Entiende que para conseguir los dos rostros, las dos caras del muro, necesita dos superficies, dos pieles, que en este caso son dependientes entre sí para poder sujetarse, generando un solo sistema que finalmente trabaja como una gran piel aligerada, en este caso hueca y compleja.

La solución autoportante que desarrolla es heredada de construcciones en rotación romanas como el Panteón, junto al aparejo de ladrillo en espina de pez islámico y las ya conocidas nervaduras góticas; todo ello le permiten desarrollar con una ecléctica mezcla de sistemas un modo de levantar ese volumen de cuarenta y dos metros de diámetro a cuarenta y dos metros de altura, todo en ladrillo macizo. La cesta estructural de la cáscara interior generaba una serie de nervaduras externas inconvenientes para la imagen de la fachada, que se soluciona a través de una segunda piel que arriostra, con una imagen urbana ligera (como si enfundáramos una jaula con una media). Ambas capas permiten que el espacio intersticial fuera transitable, facilitando así la construcción de la cáscara exterior. Todas las capas traba-

However, six meters behind that twenty-five meter-high cylindrical wall, we can see how its exterior facade does no longer respond to its urban context in such moving way. It has not endured the passing of time as the interior side has.

It is therefore interesting to stop for a minute and think about how the more primitive constructions enclose the most abstract concept: a wall, with two sides and three layers (two of which are skins with no thickness and with texture; and surround an interior, invisible one). We will now see what occurs when such immediate conception of matter begins to be distorted, evolving towards the search of other spatial sensations.

Master Brunelleschi takes an important step through constructive technique precisely in the realm we intend to analyze. He designs in 1420 the dome of Florence's cathedral, in which urban presence is given priority. The volume must be placed at an excessive height, for which its construction becomes complicated. The interest is precisely the opposite to that of the Pantheon: here the essential aspect is that of the exterior skin. Its viability therefore goes through a thought process on how to lighten it up: it is not possible to chisel the matter in a primitive way. Brunelleschi does so through two layers, where each responds to its correspondent space: the interior one to the temple's crossing and the exterior
Fig. 5. Brunelleschi: Cúpula de Santa María de las Flores. 
jan como una sola desde el punto de vista dinámico y mecánico. No es tan inmediata la radiografía de esta piel múltiple, que paradójicamente, mantiene la ética constructiva de los muros macizos.

Hasta ahora hemos visto como el término 'piel' va cambiando de significado según la obra descrita. Una piel puede ser desde una superficie casi sin espesor hasta un sistema de complejo de varias cáscaras paralelas. Al tratarse de una metáfora, es necesario definirla antes de incorporarla a un discurso para evitar confusiones.

Los sistemas constructivos evolucionan y en el siglo xIX se van abandonando las técnicas murarias, abriéndose progresivamente un campo expresivo enorme con el uso mayoritario del hierro y el hormigón en las ciudades. Esos descubrimientos hacen que en el siglo $\mathrm{xx}$ los arquitectos tomen conciencia de grupo social influyente y adopten de nuevo decisiones dogmáticas en los congresos de los CIAM, hacia una nueva arquitectura. Le Corbusier en 1926, propone sus 'cinco puntos' y deliberadamente el cuarto es separar la piel de la estructura: la fachada libre. Con ello se abre paso a un magnífico mundo expresivo que algunos críticos defienden que se agota tras el paradigmático trabajo de Mies Van der Rohe realizado en 1945: la Casa Farnsworth, donde la piel exterior se desvanece perimetralmente. Esta obra, lejos de llevar la arquitectura hacia un rigor técnico cada vez más intenso, parece olvidarse desvaneciéndose el hallazgo en el tiempo, dando paso a una complejidad mas frívola y fácil por atender a modas que aún continúan confundiéndonos.

No obstante, el racionalismo sigue la gramática clásica en la que el muropiel desarrolla sus propias reglas formales. Sin embargo, surge el organicismo, donde la piel exterior es necesariamente la expresión natural del interior, donde coherentemente con el esqueleto ha de ser armónica. Esa transgresión genera pieles estructurales fantásticas, que curiosamente nos acercan al planteamiento primitivo del muro desnudo y crudo como elemento a doble cara generador de espacios. Por eso, parece conveniente pararse en los años cincuenta, con un arquitecto que aunque habitual-

one to the city.Brunelleschi understands that in order to achieve both faces, he needs two surfaces, two skins, which in this case are dependent on each other to sustain themselves, generating a single system that finally works as a lightened skin, in this case hollow and complex. The self-supporting solution developed by Brunelleschi is inherited from roman constructions such as the Pantheon, together with Islamic corner brick bonding and the well-known Gothic arch ribs, all of which enable him to develop through such eclectic mix of systems a means of elevating that volume of forty-two meters of diameter, to a height of forty-two meters, all in massive brickwork.

The structure of the internal shell generated a series of external ribs that were inconvenient for the external image of the facade. This was solved through a second fastening skin with a light urban image (as if we encased a cage inside a stocking). Both layers allow the interstitial space to be open for transit, thus bringing ease to the construction of the exterior shell. Both layers work as one from dynamic and mechanic points of view. This multiple skin's radiography is not so immediate, but it paradoxically maintains the constructive ethic of massive walls. 
mente se le adscribe al organicismo, pensamos que en su obra resuenan inquietudes más clásicas.

Jørn Utzon abre un camino sorprendente y aparentemente contradictorio con respecto al defendido por el Movimiento Moderno. Esta imagen, extraída de uno de los fragmentos de una entrevista televisada tras haber sido premiado, explica su discurso: defiende que el exterior no tiene porqué ser una forma 'parlante' de lo que dentro pase. Las dos capas, interior y exterior son diferentes porque responden a situaciones muy distintas.

Con el proyecto de la Ópera de Sidney, en 1956, abre un capítulo donde su narrativa justifica que el intersticio entre ambas pieles no tiene por qué estar habitado.

¿Sería consciente de estar alimentando el argumento constructivo de la división de pieles que utilizará diez años después el posmodernismo, o solo se trata de su personal forma de pensar, para poder saltar los límites pragmáticos que propugna el movimiento moderno?

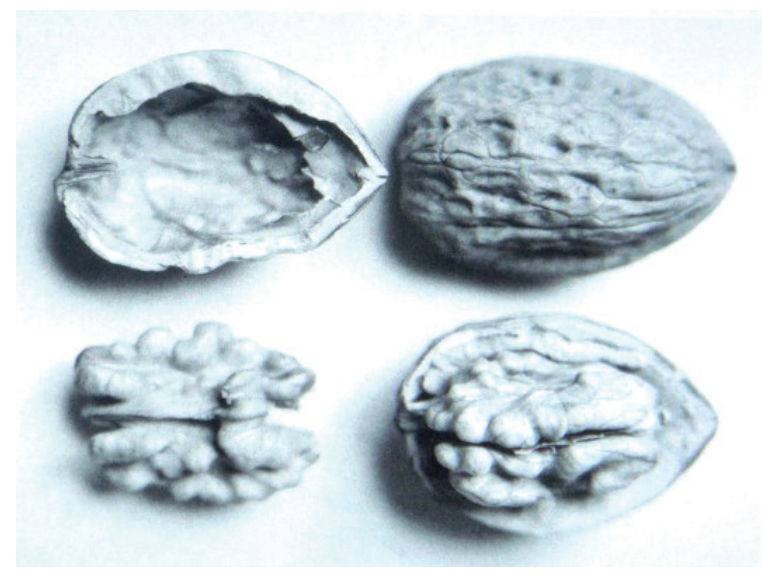

complex system of various parallel shells. Being a metaphor, it is necessary to define it before incorporating it into a discourse, in order to avoid confusions.

Constructive systems evolve, and in the Twentieth Century masonry techniques begin to be abandoned, a new, huge expressive field opening up progressively with the use of iron and concrete in cities. Through such discoveries, architects in the Twentieth Century take consciousness as an influent social group, and readopt dogmatic decisions in the CIAM Congresses towards a new architecture. Le Corbusier, in 1926, proposes his 'five points', of which the fourth one is to deliberately separate skin from structure: the free façade. Through that, he opens up to a magnificent expressive world that some critics defend runs out after the paradigmatic work of Mies Van der Rohe, in 1945, with the Farnsworth House, where external skin vanishes along the perimeter. This work, far from taking Architecture towards an increasingly intense technical rigor, seems now to be forgotten, vanished in time, taking a step aside for a new, frivolous complexity ready to respond to temporary trends that continues to confuse us today.

Nevertheless, rationalism follows the classic grammar in which the wall-skin develops its own formal rules. Organicism, however, emerges where exterior skin is necessarily the natural expression of the interior, where it must be harmonic in coherence with the skeleton. Such transgression generates fantastic structural 


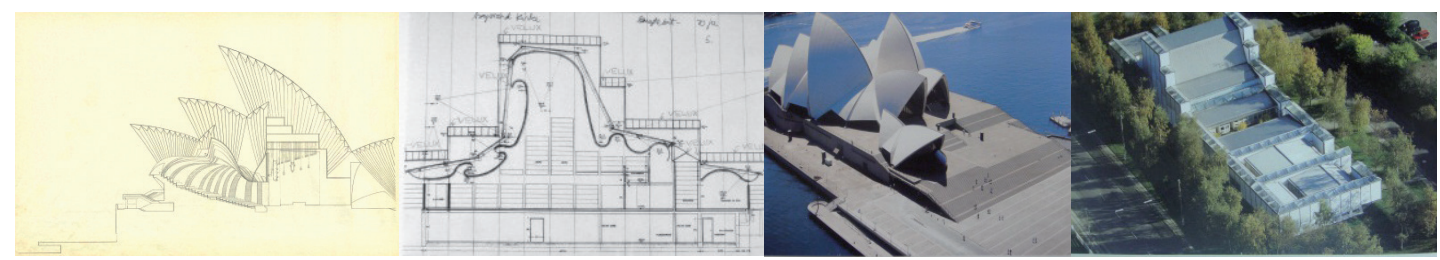

Utzon parece que recoge el valor de la experiencia masiva clásica, donde se cincelan de distinta forma las dos caras de un mismo muro, ahora según su teoría, duplicando dialécticamente la piel, para producir una sola cosa más compleja, operando en base a como lo hizo Brunelleschi. Arriesga investigando con nuevos sistemas constructivos traídos de la ingeniería y deja de lado muchos de los preceptos del Movimiento Moderno sin rechazar su estética, aunque posiblemente sí su ética.

Al comparar dos de sus obras maestras (Ópera de Sydney y Parroquia de Bagsvaerd) se observa que trabaja similarmente en ambas, pero utilizando las capas de materia de forma contraria. Eso nos lleva a pensar que es una sistemática proyectual, quizás más determinada por necesidades perceptivas que constructivas.

En Sidney cuelga la membrana ligera de madera (concha acústica) de la pesada gran cáscara exterior, que consigue el volumen necesario para escalar el perfil que requiere la ciudad. Sin embargo, en Bagsvaerd hace lo contrario, posa la membrana ligera que solo responde al clima sobre la cáscara sinuosa y rígida de hormigón. El inquietante colchón vacío intersticial en ambas obras es inhabitable, es pretendidamente hueco, algo que indudablemente pensó que necesitaba para responder a los estímulos que consideró más importantes. No esconde nunca que se trata de dos pieles con unas leyes constructivas completamente distintas. A nadie se le ocurre denominarlas como una sola piel, seguramente porque no han sido pensadas para que trabajen mecánicamente juntas, solo cohabitan.

Estas duplicidades no se tratan de estrategias que no se hayan utilizado antes en la historia de la Arquitectura; las cubiertas de madera que cubren cual-

skins that curiously approach us to the primitive proposal of a stripped and crude wall as a double-faced element, generator of spaces. For this reason, it seems convenient to stop in the 50's with an architect whose oeuvre, whilst usually being ascribed to organicism, we think resonates with more classical concerns.

Jørn Utzon opens up a surprising and seemingly contradictory path with regard to the defended Modern Movement. This image, extracted from one of the fragments of a televised interview after having been awarded, explains his discourse. He defends that there is no reason for the exterior skin to be a 'speaking' form of what happens in the interior. Both skins, interior and exterior, are different because they respond to very different situations. With the 1956 Sydney Opera, he opens up a new chapter, where the narrative justifies that the interstice between the two skins does not necessarily have to be inhabited.

Was he aware that he was feeding the constructive argument of skin division that was to be used ten years later by Posmodernism, or was it only his personal thought process in order to jump over the pragmatic limits advocated by the Modern Movement? Utzon seems to collect the value of the massive classic expertise, where both faces of a same wall are chiseled in different ways. Now, with his theory, dialectically duplicating the skin in order to produce a single,
Figs. A, B y C. Utzon, Jørn: Ópera de Sydney, 1973. Fig. D. Utzon, Jørn: Parroquia de Bagsværd, 1976. 

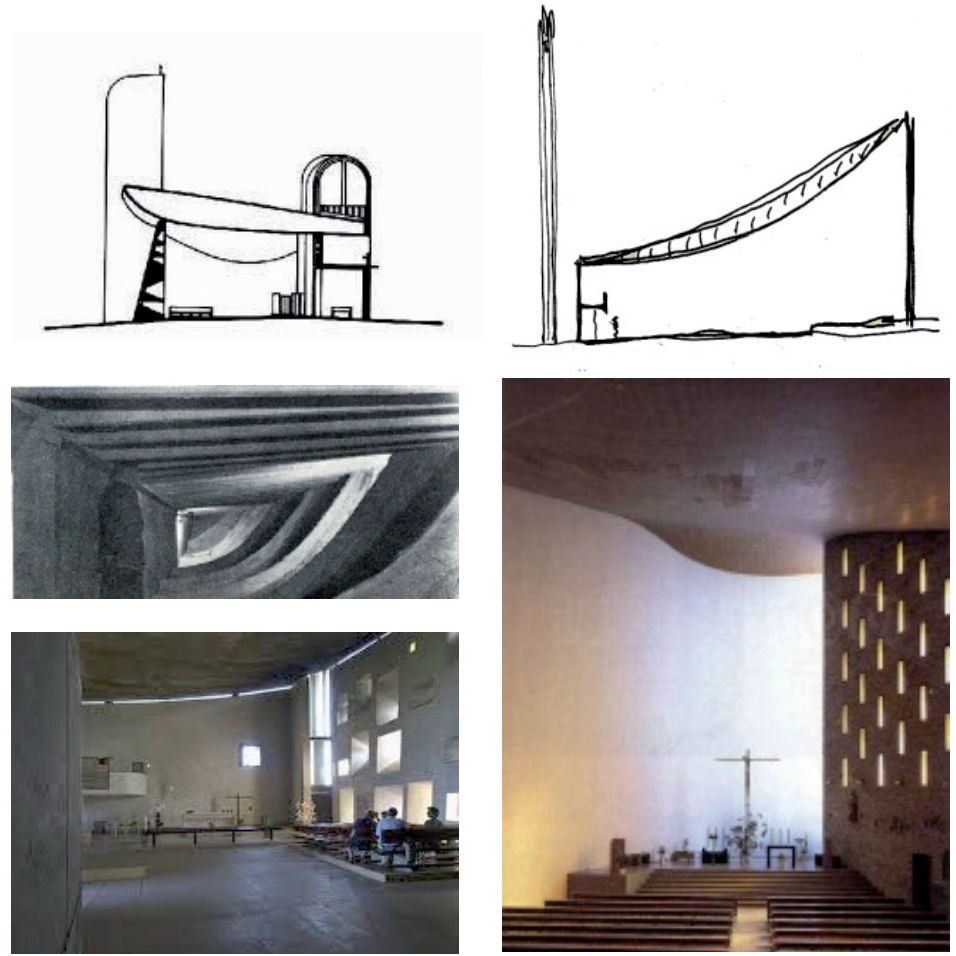

quier catedral gótica, transforman su perfil sobre el orden pétreo donde se apoyan. De hecho, es un tema con el que han flirteado grandes arquitectos del Movimiento Moderno. Justamente, solo vamos a fijarnos ahora en otras tres obras más de estos mismos años cincuenta.

En la capilla de Ronchamp, de 1952, (Fig. 6) sólo cuatro años antes del proyecto de la ópera, Le Corbusier hincha la estructura consiguiendo doblar el muro a sur y la cubierta; tensando la lámina superior y resolviendo con un solo gesto que la imagen exterior exprese frente al paisaje un volumen

more complex thing, he operates on the same basis as Brunelleschi. He takes a risk investigating with new constructive systems brought from engineering and leaves behind many of the precepts of the Modern Movement without rejecting its aesthetics, although possibly doing so with its ethics.

In comparing these two master pieces (the Sydney Opera and the Bagsvaerd Parish), we can observe that he works similarly in both, but utilizing the layers of matter in opposite ways. This brings us to thinking that it is a design systematic, perhaps determined more so by perceptive than by constructive needs.

In Sydney, he hangs a light wooden membrane (acoustic shell) from the exterior's heavy, great shell, which achieves the necessary volume to define the profile required by the city. In Bagsvaerd, he does the opposite, placing the light membrane that only responds to climate over the sinuous and rigid internal concrete shell. The disturbing interstitial empty chamber is not inhabitable in both cases, but it is intentionally hollow, something which he thought was needed to respond to the stimuli he considered most important. He never hides their condition, as two skins with completely different constructive laws. Nobody ever thinks of dominating a single skin, surely because they have not been thought of to work mechanically as one, they only coexist.
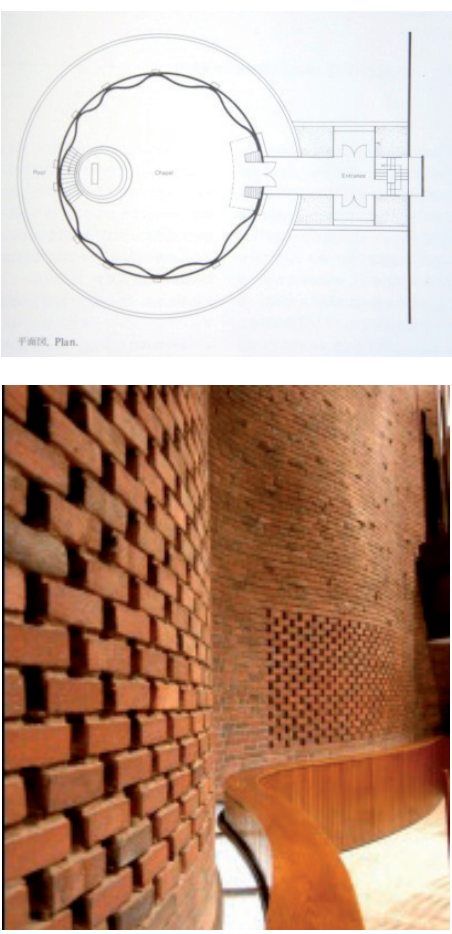

Fig. 6. Le Corbusier: Ronchamp, 1952.

Fig. 7. Fisac, Miguel: Iglesia de la Coronación, Vitoria, 1957.

Fig. 8. Saarinen, Eero: Capilla en MIT, 1955. 
enorme, cuando el interior es mucho menor y contenido. Único ejemplo en su obra. Por esos años, Eero Saarinen, en la capilla del MIT de 1955, (Fig. 8) duplica la hoja interior de ladrillo haciéndola vibrar de forma independiente al cilindro exterior que la tensa, provocando también incómodos espacios intersticiales. En España, incluso Fisac, en 1957, con la Iglesia de la Coronación de Vitoria, (Fig. 7) también busca expresar con dos láminas una espacialidad interior lisa, con la superficie inferior de la cubierta lenticular, muy distinta a la textura externa, atando sutil y sinuosamente los dos muros verticales de cierre, el dinámico curvo y blanco frente al estático, oscuro, recto y troquelado.

Ninguno de los tres arquitectos mencionados es sospechoso de abusar de esta práctica proyectual en sus obras, la cual es tan fértil como peligrosa, pero sí han experimentado al final de su carrera un interés especialmente intenso por la textura epitelial de la materia en detrimento de otros aspectos. Esa fácil sistemática de la superposición de capas abrirá las puertas al Posmodernismo, el cual desvinculará la piel de la representación exterior y del orden interno, sin pudor.

Robert Venturi entró en 1954 en el estudio de Eero Saarinen y empezó ayudando a desarrollar la capilla del MIT. En esos meses también se estaba fallando el concurso de la Ópera de Sydney, en la que Saarinen fue jurado. En 1962 escribe Complejidad y Contradicción y respalda con sus teorías el Posmodernismo. Esta corriente descubre la gran aceptación social que tiene utilizar la arquitectura como soporte publicitario, con simples metáforas de la forma justificadas por el marketing de una incipiente sociedad de consumo. Se aplica la extravagancia como herramienta de atención, en lugar de la bella proporción o la lógica constructiva, que tan magníficas arquitecturas produjo el Movimiento Moderno. En el momento en que algo no llama la atención, ya no sirve y se transforma. Solo con cambiar la máscara, el objetivo se reactiva. Esa trasgresión surge al permitir que la piel expresiva de la arquitectura trabaje de forma independiente y autónoma al orden interno del resto del edificio, iprecisamente el cuarto punto de Le Corbusier!

These duplicities are not strategies never been used before in the history of Architecture: the wooden canopies of any gothic cathedral transform their profile over the petrous order where they find support. It is indeed a theme with which great architects of the Modern Movement have flirted. We are only going to look at another three works of the same 50's.

In the chapel at Ronchamp (Fig. 6) (1952), only four years before the opera project, Le Corbusier inflates the structure, managing to bend the southern wall and the canopy. By tensioning the upper layer he achieves through a single gesture the external appearance's expression of a huge volume towards the landscape, while keeping the interior much smaller and contained. This is a unique example in his oeuvre. In those years, Eero Saarinen, in the chapel at MIT (Fig. 8) (1955), duplicates the internal brick layer, making it vibrate independently from the external cylinder that tenses it, provoking once again uncomfortable interstitial spaces. In Spain, even Fisac, in 1957, with La Coronación Church in Vitoria (Fig. 7), also seeks to express through two layers a smooth interior spatial quality with the internal lenticular surface of the canopy, which is very different from the external texture. He thus subtly and sinuously ties the two enclosing vertical walls: one curved, white and dynamic and the other, static, dark, and straight. 


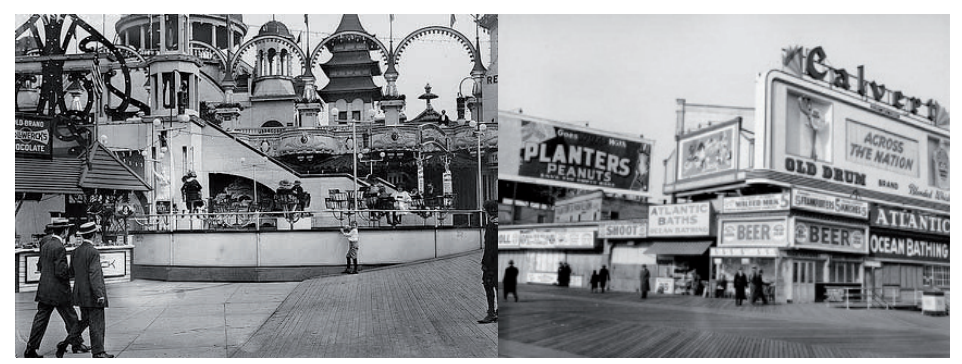

Es importante recordar, que también en los años cincuenta surgen experimentos donde la piel es protagonista, gracias a la incorporación de membranas y sistemas ligeros, llegando a utilizar el aire como materia estructurante. Estas líneas de investigación han ido sumando claves al momento donde nos encontramos, en base a sus descubrimientos con nuevos materiales plásticos, hinchables y estructuras mínimas rescatadas de los avances de la ingeniería de posguerra. Esa mentalidad, junto al entendimiento de la primitiva arquitectura nómada, permite que maestros como Frei Otto, Buckminster Fuller y posteriormente de forma más teórica Reyner Banham o el grupo Archigram, retomen esa arquitectura 'portátil', llevándola al límite y esta-
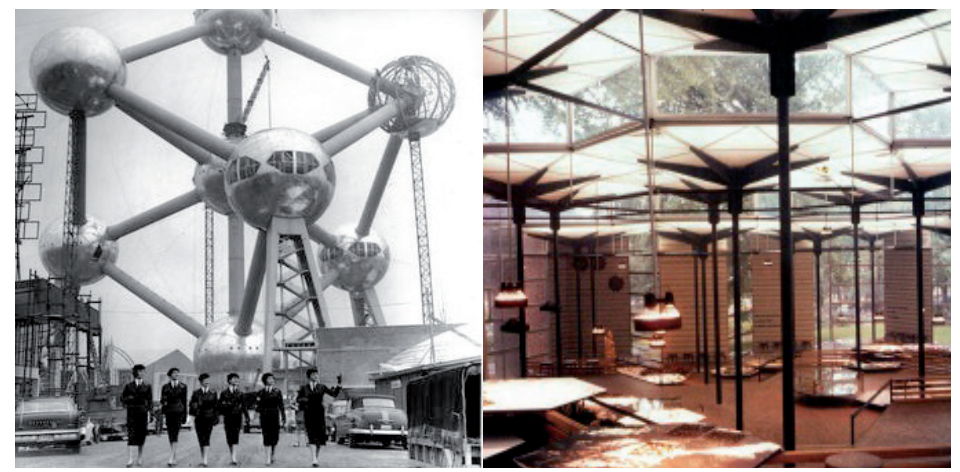

Neither of these three architects is suspect of making excessive use in their oeuvres of this design practice, which is as fertile as it is dangerous. They have however experimented towards the end of their careers an especially intense interest for the epithelial texture of matter, in detriment of other aspects. The simple systematic of the superimposition of layers will open up the doors of Posmodernism, which will detach the skin of exterior representation from that of interior order, with no reserve.

Robert Venturi entered in 1954 the office of Eero Saarinen and began helping develop the chapel at the MIT. In those months, the Sydney Opera juries were also taking place, where Saarinen was one of the board members. In 1962 he writes Complexity and Contradiction, backing up Posmodernism through his theories. This current discovers the great social acceptance of using Architecture as advertising support, through simple formal metaphors justified by the marketing strategies of an incipient consumer society. Extravagance is applied as attention-gathering tool, instead of a beautiful proportion or of the constructional logic which had produced such magnificent architectures under the Modern Movement. Whenever something does not attract attention, it is no longer useful and is therefore transformed. By the mere means of changing the mask, the objective is re-activated.
Fig. 9. Luna Park \& Boardwalk, Coney Island, 1902

Fig. 10. Atomium y Pabellón de España, Exposición Universal de Bruselas, 1958. 


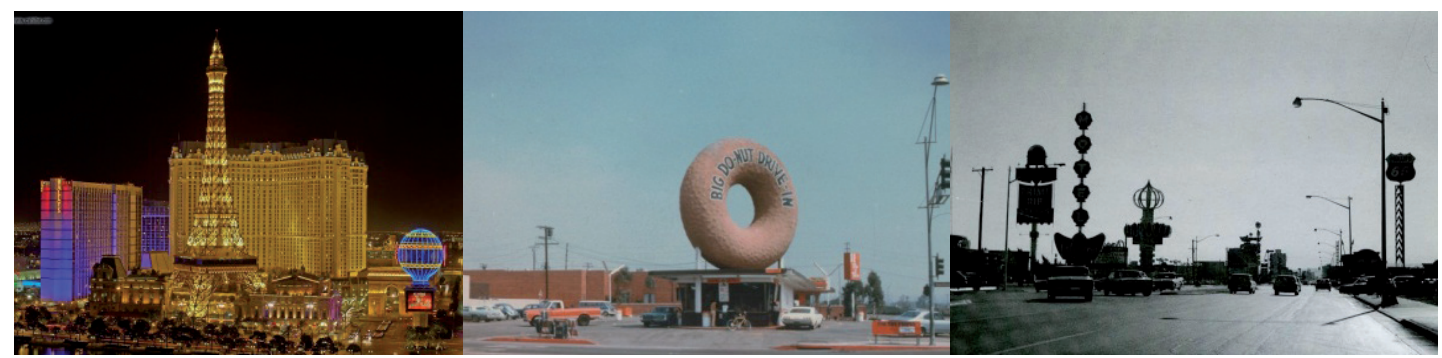

bleciéndola literalmente como una segunda piel, con la fascinante novedad Fig. 11. Las Vegas (año 2000 y 1965). de las transparencias y la gestión técnica de las tensiones. Una interesante corriente paralela que va afianzándose en los pabellones de todas las exposiciones universales.

El exceso experimental es uno de los objetivos de las exposiciones universales, donde conviven hallazgos asombrosos entre multitud de monstruos, (Fig. 10) por ejemplo, en esos años cincuenta y en la misma Exposición Universal de 1958 celebrada en Bruselas, aparece el magnífico Pabellón de España de Corrales y Molezún junto al tremendo Atomium de André Waterkeyn. Pero ahora, intentaremos incidir en el problema de la fachada como excusa publicitaria.

El discurso salta el límite que marca el recinto ferial y se socializa invadiendo la realidad urbana diaria. Ya no es algo solo temporal y periódico. Esa atracción lúdica y representativa que tiene la piel exterior de la arquitectura, se convierte en un desestabilizador metropolitano irrumpiendo en el orden y plástica de la ciudad.

En la década siguiente, la ciudad de Las Vegas (Fig. 11) crece centrando la atención en esto. Allí, la especulación formal constante es lo que mantiene activa la ciudad, no funciona como un ferial o una instalación arquitectónica temporal, donde la experimentación interesa por encima de la extravagancia, como ahora pudieran ser las interesantes iniciativas del londinense

This transgression emerges from allowing the expressive skin of architecture to work independently and autonomously from the internal order of the rest of the building, iprecisely Corbusier's 4 th point!

It is important to remember that also during the 50 's, experiments where the skin was protagonist take place, thanks to the incorporation of light membranes and systems, reaching even to the use of air as structural material. These lines of investigation have been summing up clues to the moment where we find ourselves today, based on the mentioned experiments with new plastic materials, inflatables and minimal structures rescued from post-war engineering developments. This mentality, together with the understanding of primitive nomad architecture, enables Frei Otto, Buckminster Fuller and later on in a more theoretical manner Reyner Banham and Archigram, to retake such 'portable' architecture, taking it to the limit and establishing it literally as a second skin with the fascinating novelties of transparency and the technical management of tensile forces: an interesting parallel current that begins consolidating in the pavilions of all World Fairs. 
Serpentine Pavillion o del neoyorkino PS1. Su crecimiento y origen es heredero del espíritu que hacia el año 1900 hizo posible Coney Island (Fig. 9) y que probablemente dentro de diez años sufra Eurovegas en Madrid. En Las Vegas se utiliza a la arquitectura como a una prostituta mas, su piel es un reclamo escenográfico, sin avanzar en las simples tipologías de los burdos edificios que esconden detrás.

"Ya sabemos también que no hay nada más real que lo aparente. Las Vegas pasó en el año 2000 a ser una iconografía inflada y sobrepasada por una nueva escala". (Venturi, R.: Lerning from Las Vegas, GG, MIT, 1977) "El peligro escenográfico aparece cuando todo se convierte en un teatro exótico en vez de un lugar real". (Koolhaas, R.: Harvard Project on the City 2, Taschen, MIT, 2001)

Esa banalización posmoderna es demandada actualmente por la sociedad y todavía está vigente en los centros comerciales, (Fig. 12) perversos herederos de todo esto, caricaturizando (Fig. 13) constantemente el concepto de 'piel'. Quizá todos hemos caído en la trampa de una falsa comodidad consumista, permitiendo que la implicación física del hombre en la arquitectura no sea lo prioritario. La entereza y sostenibilidad de las obras depende, no solo de la coherencia de su materia con respecto a su orden constructivo, sino a lo que finalmente es capaz de responder en el tiempo y lugar donde se construye, a la implicación emocional que en cualquier momento nos transmite.

En todos estos proyectos hay una preocupación común, la piel, sea o no estructural, cáscara o membrana, monomatérica o multicapa, es el problema más vulnerable que manipula el arquitecto, por albergar la inevitable imagen de lo construido, el límite de las cosas.

La 'buena piel' puede entonces entenderse como una secuencia variable de capas más o menos gruesas y dependientes entre ellas. Olvidar esa dependencia es el mal de la arquitectura (y líbranos del mal), como cuando nuestra piel no recibe del cuerpo los fluidos que necesita, se oxida, se cuartea,

magnificent Spanish Pavilion constructed in 1958 in the Brussels World's Fair by Corrales and Molezún, presented next to André Waterkeyn's tremendous Atomium. But now, we will try to stress on the problem of the façade as advertising excuse. The discourse jumps over the limit marked by the fair's enclosure and becomes socialized, invading daily urban reality. It is no longer something temporary and periodical. The ludic and representative attraction possessed by the external skin of architecture becomes a metropolitan de-stabilizer, bursting into the order and appearance of the city.

In the following decade, the city of Las Vegas (Fig. 11) grows, concentrating its attention on this matter. There, constant formal speculation is what maintains the city active, rather than it working as a fair or as a temporal architectural installation with an interest for experimentation above extravagance, as it may now be the case of initiatives such as London's Serpentine Pavilion or New York's PS1. Its growth and origin inherits the spirit which towards 1900 made Coney Island possible, and which will probably make Madrid suffer with Eurovegas in the next ten years. In Las Vegas, architecture is 'used' just as any other prostitute, its skin being a scenographic device; by no means developing the simple typologies of the clumsy buildings it hides behind. 
muere. La ética de nuestro trabajo podríamos decir que está relacionada con el nivel de compromiso y coherencia entre las partes que definen la arquitectura que propongamos. Al ser un complejo entramado de capas, físicas y sensitivas, no es suficiente solo incidir en la ética constructiva para proyectar arquitectura, falta un componente extraño e incómodo para la razón: el poético, el que provoca que la emoción de la experiencia arquitectónica perdure en la memoria.

"We also already know that there is nothing more real than what is appealing. Las Vegas became in the year 2000 a new inflated iconography, surpassed by a new scale". (Venturi, R.: Lerning from Las Vegas, GG, MIT, 1977)

"Scenographic danger appears when everything becomes an exotic theatre instead of a real place". (Koolhaas, R.: Harvard Project on the City 2, Taschen, MIT, 2001)

Such posmodern trivialization is demanded by society and persists nowadays in shopping malls, (Fig. 12) perverse inheritors, constantly caricaturizing the concept of 'skin'. Perhaps, we have all fallen in the trap of a false consumerist commodity, allowing for the physical implication of man into Architecture to no longer be a priority. The integrity and sustainability of buildings depend not just on the coherence of their matter, with regard to their constructive order, but rather on what is ultimately capable of responding to the time and place where they are built, on the emotional implication they transmit at any given time.

In all these works there is a common concern, the skin, be it structural or not, shell or membrane, of a single component or multi-layered, it is the most vulnerable aspect manipulated by the architect, for it hosts the inevitable image of what is built, the limit of things.

The 'good skin' can thus be understood as a variable sequence of layers of more or less thickness, dependent of each other. Forgetting this dependence is the evil of Architecture (but deliver us from evil), just as happens when our skin does not receive what it needs from the body: it oxidizes, cracks, dies. We may say that the ethic of our job is related with the level of compromise and coherence between the parts that define the architecture we propose. Being a complex framework of physical and sensitive layers, it is not sufficient to only include constructive ethic when designing architecture, there lacks a component which is strange and uncomfortable to reason: the poetic one, which causes the emotion of architectural experience to endure in one's memory. 


\section{BIBLIOGRAFÍA}

PALLASMAA, Juhani. The eyes of the skin. West Sussex: Wiley Academy, 2005.

KOOLHAAS, Rem. Delirious New York. GG, 1978.

KOOLHAAS, Rem. Harvard Project on the City 2. Taschen, MIT, 2001.

VENTURI, Robert. Learning from Las Vegas. GG, MIT, 1977.

WESTON, Richard. Jørn Utzon. Bløndal, 2002.

SAARINEN, Eero. $A+U$. Tokio: 1984.

\section{REFERENCES}

PALLASMAA, Juhani. The eyes of the skin.West Sussex: Wiley-Academy, 2005.

KOOLHAAS, Rem. Delirious New York. GG, 1978.

KOOLHAAS, Rem. Harvard Project on the City 2. Taschen, MIT, 2001.

VENTURI, Robert. Learning from Las Vegas. GG, MIT, 1977.

WESTON, Richard. Jørn Utzon. Blondal, 2002.

SAARINEN, Eero. $A+U$. Tokyo: 1984. 